\title{
Comparative analysis of effectiveness of some students' physical culture training methodic
}

\author{
Osipov A.Yu. ${ }^{1,4}$, Kudryavtsev M.D. ${ }^{1,2,5}$, Iermakov S.S. ${ }^{3}$, Yanova M.G. ${ }^{5}$, \\ Lepilina T.V. ${ }^{2}$, Plotnikova I.I. ${ }^{6}$, Dorzhieva O.S. ${ }^{7}$ \\ ${ }^{1}$ Siberian Federal University, Krasnoyarsk, Russia \\ ${ }^{2}$ Reshetnev Siberian State Aerospace University, Krasnoyarsk, Russia \\ ${ }^{3}$ Kazimierz Wielki University, Bydgoszcz, Poland \\ ${ }^{4}$ V.F. Voino-Yasenetsky Krasnoyarsk State Medical University, Krasnoyarsk, Russia \\ ${ }^{5}$ Krasnoyarsk State Pedagogical University of V.P. Astafyev, Krasnoyarsk, Russia \\ ${ }^{6}$ Irkutsk State University, Irkutsk, Russia \\ ${ }^{7}$ Buryat State University, Ulan-Ude, Russia
}

\begin{abstract}
Purpose:

scientific researches witness about presence of serious tendency to weakening students' everyday motor activity and absence of motivation to physical culture and sports practicing. Some specialists offer to solve this problem by making physical culture classes more oriented on sports. At the same time there are studies, offering to use methodic of cardio-power training. Comparative analysis of effectiveness of different programs on Physical culture trainings with the help of sport oriented approach and functional-power training. The main criterion of trainings' effectiveness was the level of physical and functional fitness of students' organism to physical loads.

Material: in the research students ( $n=600$ : boys $-n=300$, girls $-n=300$, age $-19-20$ years) participated. Selection of students was fulfilled, considering indicators of body mass. We used the methods of physical condition control and assessment (control tests) and functional fitness (functional tests). Besides, we considered indicators of busy mass by students' regular weighing.

Results: $\quad$ we found some increase of body mass of students, who attended different sport specialization trainings. Boys and girls (athletic gymnastic and ping pong) demonstrated confident body mass increase in average by 3-4 kg during academic year Students, practicing cardio-power training - HOT IRON- practically did not increase body mass. Difference in body mass indicators of such students between beginning of trainings and at the end of the researches was insignificant $( \pm 0.3 \mathrm{~kg})$. Tests' results witness about general reduction of indicators of students' main physical qualities during academic year. Significant increase of physical strength was found only in students, specializing in athletic gymnastic (boys and girls). Students of cardio-power training - HOT IRON-demonstrated confident increase of indicators of physical strength, general endurance and flexibility.

Conclusions: $\quad$ our results witness that there is a demand in corrections of students' physical culture training methodic. Their base is programs of sport oriented physical education. With it, it is necessary to compulsory consider dynamic of body

$\begin{array}{ll} & \text { mass changes and targeted application of cardio-power training programs. } \\ \text { Keywords: } \quad \text { health, motor activity, students, physical education programs, sport-oriented approach, cardio-power training, }\end{array}$ physical condition, functional fitness.
\end{abstract}

\section{Introduction}

In modern higher education students' physical education endures rather serious changes [4]. It has been found that substantial intensification of educational process served as significant factor of students' everyday motor activity weakening $[5,17,21]$. One more important factor of negative influence on students' health is their excessive involvement in computer games and internet $[3,20,22]$. Deficit of students' everyday motor activity results in emersion of different diseases, excessive increase of body mass and obesity $[6,25,34,40]$.

Specialists in the field of physical education offer to solve the problem of students' insufficient motor activity by increasing the level of motivation settings to regular physical culture and sports practicing $[27,24,46]$. It is known that students' motivation is very important in physical culture and sports [7, 2, 9, 19]. Many students consciously do not attend academic physical culture classes, thinking that they are not important for them. One more reason of low motivation is absence of proper attention of universities' administration to sport facilities condition [26]. This problem is very urgent as far as at present time organization and methods of physical culture trainings do not meet modern requirements [23]. (c) Osipov A.Yu., Kudryavtsev M.D., Iermakov S.S., Yanova M.G., Lepilina T.V., Plotnikova I.I., Dorzhieva O.S., 2017 doi:10.15561/20755279.2017.0405
Specialists say that there is an acute demand in realization of students' health improvement programs as quick as possible (both bachelor and masters students) $[30,51]$. In scientists' opinion modern physical education programs for students shall be directed at the following: increase of cultural level; preservation of psychic health; formation of steady motivations for healthy life style $[8,21,11]$.

Specialists say that physical education methodic, oriented on sport oriented approach to trainings' organization and fulfillment corresponds to the largest extent to the mentioned conditions [13, 28, 49]. Different studies show that there is noticeable positive correlation between physical culture trainings on the base of sport-oriented approach and students' psycho-physical qualities [10, 43, 45, 47]. Increase of level of young people's professional-applied physical fitness for future professional activity [42]. Scientific works witness that different sport mass competitions influence positively on students' psychic health [16].

At the same time in literature there are data about use of individualized physical education of students [31]. Scientists found that boy-students' physical activity level is higher than the same of girl-students [12]. Therefore, physical education programs, considering students' main demands will be wanted [37]. The studies show that the main demand of girls is physical attractiveness of body: 
beauty of lines, flexibility, plasticity and grace [1, 29]. Boys prefer physical qualities: strength, endurance and quickness 14]. In specialists' opinion such demands can be satisfied completely by methodic of cardio-power training. In the base of such methodic there are power exercises, fulfilled under rhythmic music [29, 32]. Application of such exercises permitted to substantially increase students' (boys and girls) physical fitness. Such approach will permit to successfully resist global threat - obesity of modern youth [44]. Specialists also note high students' interest to physical training on the base of functional and power training (fitness, cross-fit, HOT IRON) $[29,48]$.

At present, it is admitted by specialists that students' everyday way of life is a decisive factor of their professional longevity and health [38]. The main component of healthy life style will be optimal level of modern young people's everyday motor activity $[33,36]$. It is known that optimal level of everyday motor activity is a protective barrier against many not catching diseases [17]. In scientists' opinion just the programs of physical culture trainings, based on sport-oriented approach and individualized functional-power training will be able to ensure optimal level of modern young people's everyday motor activity. At the same time among scientists there no single opinion about the most effective programs of young people's (schoolchildren and students) physical education.

Hypothesis: it is assumed that comparative analysis of recommended by specialists, practical trainings' methodic will facilitate finding of the most effective methodic. These programs are: trainings on the base of profound practicing of a kind of sports; trainings on the base of power and functional training.

The purpose of the research: is determination of the most effective program for students' physical and functional fitness and methodic of physical culture practical classes in universities.

\section{Material and methods}

Participants: in the research students ( $\mathrm{n}=600$ : boys $\mathrm{n}=300$, girls $-\mathrm{n}=300$, age $-19-20$ years) participated. All the tested were the students of Siberian federal university. Selection of students was fulfilled, considering indicators of body mass. Mass range of boys' bodies was 75.9 - 79.1 $\mathrm{kg}$. Mean value of boys' body mass was $77.5 \mathrm{~kg}$. Mass range of girls' bodies was $47.9-52.3 \mathrm{~kg}$. Mean value of girl's' body mass was $49.8 \mathrm{~kg}$. All students gave their consent for participation in the research.

Organization of the research: the researches were conducted during academic year. Students (boys and girls) were divided into two equal groups. The students attended physical culture classes of certain specialization, by their choice (trainings, based on profound practicing of definite kind of sports). For our studies we chose the most popular among students, specializations: athletic gymnastic, boxing, basketball, volleyball, ping pong. Two students' groups (boys and girls) attended trainings, based on cardio-power training (HOT IRON) [32]. It should be noted that HOT IRON trainings at high quality are possible only through specialized training. In Russian Federation only a few HEE teachers have international certificates of HOT IRON instructors. Therefore, practicing of students' trainings on the base of such programs contains element of scientific novelty.

At the beginning and at the end of the research all students passed a number of tests for general physical fitness. It permitted to rather objectively assess the students' physical condition and functional fitness. It is known that main parameters of physical workability have strong correlations with human physical fitness [41]. General physical fitness is a necessary component of person's physical health [39]. Insufficient physical fitness negatively influences on human physical health in general.

Strength was assessed by quantity of chin ups (for girls it was the quantity of pressing ups from the floor). Endurance was assessed by time of 3000 meters' run (for girls - 2000 meters' distance). Quickness was registered by time of 100 meters' run. Forward bending in sitting position was the test for flexibility. Functional fitness was assessed by results of Martinet's test. Besides, every month we regularly measured students' body mass. The purpose of weighing was to control dynamic of body mass changes under influence of differently oriented physical exercises.

Statistical analysis was fulfilled with the help of SPSS20 program. Results of mean values in two interconnected samples were carried out with Student's t- test.

\section{Results}

At the beginning of the researches, by results of control tests we did not find confident differences. Boys and girls demonstrated approximately equal potential of muscular strength, general endurance, flexibility and quickness. Results of functional test (Martinet's test) also witnessed about prevalence of normosthenic type of reaction to physical load in majority of students. In average, in boys normosthenic type of reaction was found in $93 \%$ and in girls - in $86 \%$. Body mass indicators were in average: in boys $-77.5 \mathrm{~kg}$ and in girls $-49.8 \mathrm{~kg}$.

At the end of the researches we found distinctions in control tests' results and, sometimes, rather substantial. Students (athletic gymnastic: boys and girls demonstrated significant $(\mathrm{P}<0.05)$ increase of physical strength indicators and insignificant reduction of flexibility and quickness (boys). In girls worsening of quickness indicators was confidently significant $(\mathrm{P}<0.05)$. Besides, we found noticeable $(\mathrm{P}<0.05)$ reduction of general endurance indicators and worsening of Martinet test's results. Mean values of students' body mass (athletic gymnastic - boys and girls) increased confidently in average by $4 \mathrm{~kg}$.

Students (boxing: boys and girls) increased physical strength and flexibility indicators insignificantly. These students demonstrated not confident worsening of quickness and general endurance indicators. Functional 
fitness of organism to loads (Martinet's test) was confidently $(\mathrm{P}<0.05)$ less than at the beginning of the research. Mean values of students' body mass (boxing) increased insignificantly (within $1 \mathrm{~kg}$ ).

In students (boys and girls - basketball) we found insignificant increase of physical strength indicators at the end of the researches. General endurance, flexibility and quickness worsened a little. Martinet test's results point at reduction of quantity of students, having normosthenic type of reaction to physical loads. Weighing showed that body mass of the tested students increased in average by $1.7 \mathrm{~kg}$. Increase of girls' body mass was statistically significant (in average by $2.2 \mathrm{~kg}$ ).

Young people (boys and girls - volleyball) demonstrated insignificant reduction of physical strength, general endurance, quickness and flexibility at the end of the research. We also registered worsening of positive results by type of organism's reaction to physical load (not confident. Body mass indicators increased in average by $2 \mathrm{~kg}$ in boys and $1 \mathrm{~kg}$ in girls.
Students (boys and girls - ping pong) demonstrated insignificant reduction of flexibility and quickness indicators. Physical strength remained practically at the level, which was at the beginning of experiment. We found significant $(\mathrm{P}<0.05)$ weakening of general endurance and statistically significant reduction of Martinet test's results. Body mass confidently $(\mathrm{P}<0.05)$ increased in average by $3 \mathrm{~kg}$ in boys and by $2.6 \mathrm{~kg}$ in girls.

Students (boys and girls - HOT IRON) demonstrated confidently significant $(\mathrm{P}<0.05)$ increase of physical strength, general endurance and flexibility indicators at the end of experiment. Quickness increased insignificantly. Martinet test's results point at reduction of quantity of students (boys and girls), having normosthenic type of reaction to physical loads. Body mass indicators increased not confidently, within $0.3 \mathrm{~kg}$ and insignificant reduction (within $0.2 \mathrm{~kg}$ ) in girls.

Complete results of the researches are shown in tables 1 and 2 .

Table 1. Indicators of physical condition and functional fitness of the tested students (boys $-\mathrm{n}=300$ )

\begin{tabular}{|c|c|c|c|c|c|c|c|c|c|c|c|c|}
\hline \multirow{3}{*}{$\begin{array}{l}\text { Training } \\
\text { programs }\end{array}$} & \multicolumn{12}{|c|}{ Description of indicators } \\
\hline & \multicolumn{2}{|c|}{ Strength } & \multicolumn{2}{|c|}{ Quickness } & \multicolumn{2}{|c|}{ Endurance } & \multicolumn{2}{|c|}{ Flexibility } & \multicolumn{2}{|c|}{$\begin{array}{l}\text { Martinet's } \\
\text { test }\end{array}$} & \multicolumn{2}{|c|}{ Body mass } \\
\hline & $\mathbf{H}$ & 0 & $\mathrm{H}$ & 0 & H & 0 & H & 0 & H & 0 & $\mathrm{H}$ & 0 \\
\hline \multicolumn{13}{|l|}{ Athletic } \\
\hline $\begin{array}{l}\text { gymnastic } \\
(\mathrm{n}=50)\end{array}$ & $18 \pm 4$ & $23 \pm 2 *$ & $13 \pm 0,7$ & $14 \pm 0,9$ & 13,25 & $14,25^{*}$ & $6 \pm 4$ & $6 \pm 3$ & $\mathrm{H}-46$ & $\mathrm{H}-34^{*}$ & 78,3 & $82,4^{*}$ \\
\hline $\begin{array}{l}\text { Basketball } \\
(n=50)\end{array}$ & $11 \pm 4$ & $12 \pm 4$ & $12 \pm 0,6$ & $13 \pm 0,4$ & 13,05 & 13,20 & $8 \pm 3$ & $9 \pm 3$ & $\mathrm{H}-45$ & $\mathrm{H}-38$ & 76,2 & 77,9 \\
\hline $\begin{array}{l}\text { Boxing } \\
(n=50)\end{array}$ & $13 \pm 4$ & $15 \pm 3$ & $12 \pm 0,9$ & $13 \pm 0,5$ & 13,10 & 13,22 & $9 \pm 2$ & $9 \pm 4$ & $\mathrm{H}-47$ & $\mathrm{H}-37^{*}$ & 78,5 & 79,8 \\
\hline $\begin{array}{l}\text { Volleyball } \\
(n=50)\end{array}$ & $10 \pm 3$ & $10 \pm 4$ & $13 \pm 0,1$ & $14 \pm 0,1$ & 13,22 & 13,40 & $9 \pm 3$ & $9 \pm 4$ & $\mathrm{H}-46$ & $\mathrm{H}-40$ & 79,1 & 81,1 \\
\hline $\begin{array}{l}\text { Ping pong } \\
(n=50)\end{array}$ & $8 \pm 2$ & $8 \pm 3$ & $13 \pm 0,3$ & $14 \pm 0,6$ & 13,16 & $14,20 *$ & $7 \pm 3$ & $6 \pm 2$ & $\mathrm{H}-45$ & $\mathrm{H}-32 *$ & 75,9 & $79,2^{*}$ \\
\hline $\begin{array}{l}\text { HOT IRON } \\
(n=50)\end{array}$ & $10 \pm 2$ & $15 \pm 4 *$ & $13 \pm 0,9$ & $13 \pm 0,1$ & 13,35 & $12,40^{*}$ & $8 \pm 4$ & $13 \pm 2 *$ & $\mathrm{H}-46$ & $\mathrm{H}-44$ & 78,4 & 78,7 \\
\hline
\end{tabular}

Notes:* - P<0.05 - level of significance

Table 2. Indicators of physical condition and functional fitness of the tested students (girls $-n=300$ )

\begin{tabular}{|c|c|c|c|c|c|c|c|c|c|c|c|c|}
\hline \multirow{3}{*}{$\begin{array}{l}\text { Training } \\
\text { programs }\end{array}$} & \multicolumn{12}{|c|}{ Description of indicators } \\
\hline & \multicolumn{2}{|c|}{ Strength } & \multicolumn{2}{|c|}{ Quickness } & \multicolumn{2}{|c|}{ Endurance } & \multicolumn{2}{|c|}{ Flexibility } & \multicolumn{2}{|c|}{$\begin{array}{l}\text { Martinet's } \\
\text { test }\end{array}$} & \multicolumn{2}{|c|}{ Body mass } \\
\hline & H & $\mathbf{0}$ & H & 0 & H & 0 & H & 0 & $\mathrm{H}$ & 0 & H & 0 \\
\hline $\begin{array}{l}\text { Athletic } \\
\text { gymnastic } \\
(n=50)\end{array}$ & $15 \pm 2$ & $20 \pm 2 *$ & $15 \pm 0,6$ & $17 \pm 0,4^{*}$ & 11,15 & $12,25^{*}$ & $9 \pm 4$ & $8 \pm 3$ & $\mathrm{H}-44$ & $\mathrm{H}-32 *$ & 48,7 & $52,9 *$ \\
\hline $\begin{array}{l}\text { Basketball } \\
(n=50)\end{array}$ & $10 \pm 3$ & $12 \pm 2$ & $15 \pm 0,3$ & $16 \pm 0,2$ & 10,45 & 11,05 & $11 \pm 3$ & $10 \pm 4$ & $\mathrm{H}-43$ & $\mathrm{H}-35$ & 51,2 & $53,4^{*}$ \\
\hline $\begin{array}{l}\text { Boxing } \\
(n=50)\end{array}$ & $12 \pm 3$ & $15 \pm 3$ & $15 \pm 0,2$ & $15 \pm 0,8$ & 10,35 & 10,52 & $11 \pm 2$ & $11 \pm 4$ & $\mathrm{H}-42$ & $\mathrm{H}-33^{*}$ & 47,9 & 48,8 \\
\hline $\begin{array}{l}\text { Volleyball } \\
(n=50)\end{array}$ & $10 \pm 2$ & $12 \pm 3$ & $15 \pm 0,4$ & $16 \pm 0,3$ & 10,40 & 11,10 & $12 \pm 3$ & $12 \pm 4$ & $\mathrm{H}-45$ & $\mathrm{H}-37$ & 52,3 & 53,4 \\
\hline $\begin{array}{l}\text { Ping pong } \\
(n=50)\end{array}$ & $6 \pm 4$ & $6 \pm 3$ & $15 \pm 0,4$ & $16 \pm 0,9$ & 11,05 & $12,20 *$ & $10 \pm 3$ & $8 \pm 2 *$ & $\mathrm{H}-44$ & $\mathrm{H}-31 *$ & 50,4 & $53,2^{*}$ \\
\hline $\begin{array}{l}\text { HOT IRON } \\
(n=50)\end{array}$ & $10 \pm 3$ & $16 \pm 2 *$ & $15 \pm 0,5$ & $14 \pm 0,9$ & 11,15 & $10,15^{*}$ & $11 \pm 4$ & $15 \pm 4 *$ & $\mathrm{H}-43$ & $\mathrm{H}-40$ & 49,8 & 49,7 \\
\hline
\end{tabular}

Notes:* $-\mathrm{P}<0.05$ - level of significance 


\section{Discussion}

The received data can cause some questions of specialists. But our data concord with some works, devoted to studying of the most effective methodic of physical culture practicing in higher educational establishments $[30,35]$. As it is known, before enrolling to definite sport specialization students are selected. Selection is fulfilled by results of tests for general physical fitness: chin ups, jumps, run and so on. Teachers enroll to specialization the most physically trained students. However, the level of fitness to technical elements of definite kind of sports in most of students is not high. Thus, most of training time is spent for training of basic technical actions. A little attention has to be paid to perfection of fulfillment of exercises and game interactions [31]. The volume of motor activity, devoted to training of new technical elements, is hot large. It explains some reduction of main indicators of students' physical condition with the time.

It should be noted also unsatisfactory quality of sport facilities in most universities for trainings on the base of sort-oriented approach. It was found that most of students can not realize to the fullest extent their potential because of deficit of sport facilities and equipment. For example, for ping-pong training of 50 students it is necessary to have 25 tennis tables. For basketball trainings such quantity of students will require 5 sites. To play any games students have to wait their turn for long time.

That is why we offer to make some corrections of structure and methodic of such trainings. Physical culture teachers shall pay attention to opportunities for increase of students' motor activity. It is possible at the account of noticeable increase of time for game and competition activity. In most of schools and HEEs of the USA and Canada physical culture classes are conducted in the form of direct competition training and competitions in football, basketball, baseball [50].

Besides, it is necessary to introduce compulsory control over changes of students' body mass. Significant changes of body mass shall be followed by correction of trainings' structure and methodic.

In its turn, methodic of functional and power training (HOT IRON) demonstrated effectiveness in prevention from obesity. Mainly, this effect is achieved by high level of motor activity and power and aerobic loads' reasonable combination. Such methodic becomes popular in different countries. For example, in China physical education programs are oriented of sport perfection with the help of fitness programs [15]. But even this methodic requires certain changes. For example specialists found need in substantial development of some professionally important for future specialist abilities: speed-power and coordination [42]. For this purpose physical culture teachers shall use at classes complexes of exercises, facilitating optimal development of such abilities.

\section{Conclusions}

1. It was found that reduction of students (boys and girls), attending sport oriented physical culture trainings, main physical condition indicators is, in a number of cases, confidently significant $(\mathrm{P}<0.05)$. Students of some specializations (athletic gymnastic, boxing, ping pong) demonstrated noticeable worsening of type of organism's reaction to physical load (Martinet's test). Students, who practiced individual cardio-power training demonstrated confident $(\mathrm{P}<0.05)$ increase of physical strength, endurance and flexibility. In most of students type of reaction to physical load remained to be normosthenic.

2. Our results showed negative dynamic of body mass increase in most of students, in average by $2.5 \mathrm{~kg}$ (boys) and $2 \mathrm{~kg}$ (girls) (during academic year. Increase of body mass takes place independently on specific of the chosen by students kind of sports. It permits to affirm that general level of motor activity (boys and girls - sport oriented approach) is not sufficient for prevention from body mass increase and obesity. Students (functional-power training) did not demonstrated noticeable body mass changes during academic year. It permits to recommend the methodic of cardio-power training as effective mean for prevention from obesity in students.

\section{Conflicts of interest}

The authors have no conflicts of interest relevant to this study.

\section{References:}

1. Allender S, Cowburn G, Foster Ch. Understanding participation in sport and physical activity among children and adults: a review of qualitative studies. Health Education Research, 2006; 21(6): 826-835. doi:10.1093/her/cyl063

2. Ardeńska A, Tomik R, Berber S. A comparison of physical education students' motivation using the Polish and Turkish versions of the academic motivation scale. Journal of Human Kinetics, 2016; 54(1): 207-218. doi:10.1515/ hukin-2016-0046

3. Arslan Y. Determination of Technopedagogical Content Knowledge Competencies of Preservice Physical Education Teachers: A Turkish Sample. Journal of Teaching in Physical Education. 2015;34(2):225-41.

4. Bartnovskay LA, Kudryavtsev MD, Kravchenko VM, Iermakov SS, Osipov AYu, Kramida IE. Health related applied technology of special health group girl students' physical training. Physical education of students, 2017; 21(1): 4-9. doi:10.15561/20755279.2017.0101

5. Bliznevsky AA, Kudryavtsev MD, Iermakov SS, Jagiello W. Formation of active-effective attitude of 12-13 years' judo athletes to sports functioning in competition period. Archives of Budo. 2016;12:101-15.

6. Cancella Carral J, Perez C. What do we know about the profile and characteristics of university physical education students? Findings from a pilot study. European Journal of Physical \& Health Education, 2010; 4(2): 65-72.

7. De Meyer J, Soenens B, Aelterman N, De Bourdeaudhuij I, Haerens L. The different faces of controlling teaching: implications of a distinction between externally and internally controlling teaching for students' motivation in physical education. Physical Education and Sport Pedagogy. 2016;21(6):632-52.

8. Druz VA, Iermakov SS, Nosko MO, Shesterova LYe, 
Novitskaya NA. The problems of students' physical training individualization. Pedagogics, psychology, medicalbiological problems of physical training and sports, 2017; 21(2): 4-12. doi:10.15561/18189172.2017.0201

9. Fernandez-Rio J, Sanz N, Fernandez-Cando J, Santos L. Impact of a sustained Cooperative Learning intervention on student motivation. Physical Education and Sport Pedagogy. 2017;22(1):89-105

10.Gordienko YV. Theoretical training in physical education of higher educational establishments' girl students. Physical education of students, 2015; 4: 3-9. doi:10.15561/20755279 .2015 .0401

11.Iermakov SS, Arziutov GN, Jagiello W. Quick training of students to judo techniques. Archives of Budo. 2016;12:1524.

12.Iermakov SS, Cieślicka M, Muszkieta R. Physical culture in life of Eastern-European region students: modern state and prospects of development. Physical education of students, 2015; 6: 16-30. doi:10.15561/20755279.2015.0603

13.Iermakov SS, Podrigalo LV, Jagiello W. Hand-grip strength as an indicator for predicting the success in martial arts athletes. Archives of Budo. 2016;12:179-86.

14.Ilnitskaya AS, Kozina ZhL, Barybina LN, Kolomiez NA, Cieślicka M., Stankiewicz B., Pilewska W. Author's internet blog as information and communication technologies in the educational space within the physical education students. Physical education of students, 2014; 18(1): 22-26. doi:10.6084/m9.figshare.903689

15.Jin A. Physical education curriculum reform in China: a perspective from physical education teachers. Physical Education and Sport Pedagogy, 2013; 18(1): 15-27.

16.Karaca A, Çaglar E, Deliceoglu G, Bilgili N. Physical activity with regard to socio-demographic variables and decisional balance perceptions for exercise among university students. Journal of Physical Education and Sport, 2016; 3: 932-939. doi:10.7752/jpes.2016.03147

17.Kondakov VL, Kopeikina EN, Balysheva NV, Usatov AN, Skrug DA. Causes of declining interest of students to employment physical education and sports. Physical education of students, 2015; 19(1): 17-21. doi:10.15561/20755279.2015.0103

18.Kozina ZL, Ol'khovyj OM, Temchenko VA. Influence of information technologies on technical fitness of students in sport-oriented physical education. Physical Education of Students. 2016;20(1):21-8. doi:10.15561/20755279.2016.0103

19.Kretschmann R. Student motivation in physical education the evidence in a nutshell. Acta Kinesiologica, 2014; 8(1): 27-32.

20.Kudryavtsev M, Kramida I, Osipov A. Influence of monitor bad habits on healthy lifestyle of students. Theory and Practice of Physical Culture, 2016; 6: 24-26.

21.Kudryavtsev MD, Kramida IE, Iermakov SS, Osipov AY. Development dynamic of healthy life style personality component in relatively healthy students. Physical Education of Students. 2016;20(6):26-33. doi:10.15561/20755279.2016.0603

22.Kudryavtsev MD, Kramida IE, Iermakov SS. Influence of studying in higher educational establishment on students' harmful computer habits. Physical Education of Students. 2016;20(5):17-23. doi:10.15561/20755279.2016.0503

23.Kvintova J, Sigmund M. Physical activity, body composition and health assessment in current female University students with active and inactive lifestyles. Journal of Physical Education and Sport, 2016;1: 627-632. doi:10.7752/ jpes.2016.s1100

24.Leirhaug PE. Exploring the relationship between student grades and assessment for learning in Norwegian physical education. European Physical Education Review. 2016;22(3):298-314.

25.Martynova V, Kapustin A. Techniques of play activity at physical education classes at specialized secondary educational establishments. International Journal of Environmental and Science Education, 2016; 11(13): 60416055.

26.Moradian K, Moradian P. The role of sports and physical education in filling University students' leisure time. European Journal of Experimental Biology, 2013; 3(3): 241-245.

27.Mouloud K, Abd Elkader B. Sport and mental health level among university students. Physical Education of Students. 2016;20(3):39-42. doi:10.15561/20755279.2016.0305

28.Olkhovy OM, Petrenko YM, Temchenko VA, Timchenko AN. Model of students' sport-oriented physical education with application of information technologies. Physical education of students, 2015; 3: 29-37. doi:10.15561/20755 279.2015.0304

29. Osipov A, Gibaeva N, Kachaeva Yu, Pereus O. The method of HOT IRON as a means of increasing the level of physical development of students and formation of their motivation for regular physical exercise. Bulletin of Krasnoyarsk State Pedagogical University named after V.P. Astafiev, 2014; 4(30): 82-86. (In Russian)

30.Osipov A, Starova O, Malakhova A et all: Modernization process of physical education of students in the framework of implementation of the state strategy for the development of physical culture, sport and tourism in the Russian Federation. Journal of Physical Education and Sport, 2016; 4: 12361241. doi:10.7752/jpes.2016.04196

31.Osipov A, Vonog V, Prokhorova O, Zhavner T. Student learning in physical education in Russia (problems and development perspectives). Journal of Physical Education and Sport, 2016; 1: 688-693. doi:10.7752/jpes.2016.s1111

32.Osipov AY, Kudryavtsev MD, Kramida IE, Iermakov SS, Kuzmin VA, Sidorov LK. Modern methodic of power cardio training in students' physical education. Physical Education of Students. 2016;20(6):34-9. doi:10.15561/20755279.2016.0604

33. Osipov AYu, Fedorova IA, Kochetkova TN, Loginov DV. Assessment of the level of physical activity of students. Problemy Sovremennogo Pedagogicheskogo Obrazovaniya, 2017; 54(3): 157-164. (In Russian)

34.Osipov AYu, Kudryavtsev MD, Gruzinky VI, Kramida IE, Iermakov SS. Means of optimal body mass control and obesity prophylaxis among students. Physical education of students, 2017; 21(1): 40-45. doi:10.15561/20755279.2017.0107

35.Osipov AYu, Pazenko VI, Akulov VYu, Dunaeva MV. The dynamics of development of the main physical qualities at students visiting various sports specializations. In the World of Scientific Discoveries, 2013; 3.3(39): 189-198. (In Russian)

36.Osipov AYu, Vapaeva AV, Antonova AV, Chizhov AYu. Impellent activity as the main means of formation of health saving competences of students. Bulletin of Krasnoyarsk State Pedagogical University named after V.P. Astafiev, 2012; 3(21): 115-119. (In Russian)

37.Petrova MM, Pronina EA, Baron II et all: The attitude of the students of Krasnoyarsk State Medical University named after professor V.F. Voino-Yasenetsky to physical activity. Siberian Medical Review, 2016; 2: 88-92. (In Russian) 
38.PetryshynAV. Structural-functional model of medical students' professional-applied physical training. Physical education of students, 2016; 5: 32-41. doi:10.15561/20755279.2016.0505

39.Pop CL. Physical and health education facing the technology challenge. Physical Education of Students. 2016;20(2):45-9.

40.doi:10.15561/20755279.2016.0207

41.Protsenko U, Pantiuk T, Romanchuk O, Danylevych M. Improvement features of the Ukrainian physical education system. Journal of Physical Education and Sport, 2016; 1: 113-117. doi:10.7752/jpes.2016.01019

42.Radziminska A, Weber-Rajek M, Lulinska-Kuklik E, Kazmierczak U, Moska W. Academic youth's health behavior. Physical education of students, 2016; 20(6): 55-62. doi:10.15561/20755279.2016.0607

43.Salatenko IO, Dubinskaya OYa. Psycho-Physical perfection of economic specialties' girl students under influence of sport-oriented technology, based on prevalence of volleyball practicing. Pedagogics, psychology, medical-biological problems of physical training and sport, 2015; 12: 103-108. doi:10.15561/18189172.2015.1216

44.Samokih II. Physical workability as the base of students' functional potentials. Physical education of students, 2016; 6: 40-48. doi:10.15561/20755279.2016.0605

45.Shubin DA, Osipov AYu, Pazenko VI, Heinz YuV. Professional-applied physical training of health saving orientation of students of higher educational institutions. Bulletin of Krasnoyarsk State Pedagogical University named after V.P. Astafiev, 2012; 2(20): 175-181. (In Russian)
46.Shutova TN, Andryushchenko LB. Young people's motor activity encouraging fitness technologies based on global approach. Theory and Practice of Physical Culture, 2017; 3: 54-56.

47.Slingerland M, Borghouts L, Jans L, Weeldenburg G, van Dokkum G, Vos S, et al. Development and optimisation of an in-service teacher training programme on motivational assessment in physical education. European Physical Education Review. 2017;23(1):91-109.

48. Vapaeva AV, Osipov AYu, Guralev VM. Preparing students of low institute for future means of improving the performance of professional aerobics. Human. Sport. Medicine, 2013; 2(13): 6-9. (In Russian)

49.Vilchez P, Ruiz F. Achievement goals in physical education and sport and physical activity in leisure on students from Spain, Costa Rica and Mexico. Journal of Physical Education, 2016; 27. doi:10.4025/jphyseduc.v27i1.e2701

50.Vyprikov DV. CrossFit to improve students" physical fitness. Theory and Practice of Physical Culture, 2017; 3: 16-20.

51. Wallhead T, Ntoumanis N. Effects of a sport education intervention on students' motivational responses in physical education. Journal of Teaching in Physical Education, 2004; 23: 4-18.

52.Warner B. An exploration of engagement, motivation and student-centered learning in physical education. Journal of Unschooling and Alternative Learning, 2015; 18(9):34-40.

53.Zaytsev AA, Kovalenko TG, Soroka BV, Ulyanov DA. Content analysis of academic physical education programs. Theory and Practice of Physical Culture, 2017; 2: 103-104.

\section{Information about the authors:}

Osipov A.Yu.; http://orcid.org/0000-0002-2277-4467; Ale44132272@ya.ru; ${ }^{1}$ Siberian Federal University; 79 Svobodny pr., Krasnoyarsk, 660041, Russia.; V.F. Voino-Yasenetsky Krasnoyarsk State Medical University; P. Zeleznyak, 1, Krasnoyarsk, 660022, Russia.

Kudryavtsev M.D.; http://orcid.org/0000-0002-2432-1699; kumid@yandex.ru; Siberian Federal University; 79 Svobodny pr., Krasnoyarsk, 660041, Russia.; Reshetnev Siberian State Aerospace University; Office A-406, 31, Krasnoyarsky Rabochy Av., 660014, Krasnoyarsk, Russia.; Krasnoyarsk State Pedagogical University of V.P. Astafyev; Ada Lebedeva Street, 89, Krasnoyarsk, 660049, Russia.

lermakov S.S.; http://orcid.org/0000-0002-5039-4517; sportart@gmail.com; Kazimierz Wielki University; Sport str. 2, of.209, 85-064 Bydgoszcz, Poland.

Yanova M.G.; http://orcid.org/0000-0003-4262-7015; ymg_boss@mail.ru; Krasnoyarsk State Pedagogical University of V.P. Astafyev; Ada Lebedeva Street, 89, Krasnoyarsk, 660049, Russia.

Lepilina T.V.; http://orcid.org/0000-0003-2851-2369; lepilinatat@mail.ru; Reshetnev Siberian State Aerospace University; Office A-406, 31, Krasnoyarsky Rabochy Av., 660014, Krasnoyarsk, Russia.

Plotnikova I...; http://orcid.org/0000-0003-4807-1679; ira.plotnikova1978@mail.ru; Irkutsk State University; Karl Marks str., 1, 664003, Irkutsk, Russia.

Dorzhieva O.S.; http://orcid.org/0000-0001-9233-6182; dorzhieva1987@gmail.com; Buryat State University; ul. Smolin, 24a, UlanUde, 670000, Russia.

Cite this article as: Osipov AYu, Kudryavtsev MD, Iermakov SS, Yanova MG, Lepilina TV, Plotnikova II, Dorzhieva OS. Comparative analysis of effectiveness of some students' physical culture training methodic. Physical education of students, 2017;21(4):176-181. doi:10.15561/20755279.2017.0405

The electronic version of this article is the complete one and can be found online at: http://www.sportedu.org.ua/index.php/PES/issue/archive

This is an Open Access article distributed under the terms of the Creative Commons Attribution License, which permits unrestricted use, distribution, and reproduction in any medium, provided the original work is properly cited (http://creativecommons.org/licenses/by/4.0/deed.en).

Received: 13.06 .2017

Accepted: 25.06.2017; Published: 10.08.2017 